Rev. Mus. Argentino Cienc. Nat., n.s.

$6(2): 227-232,2004$

Buenos Aires, ISSN $1514-5158$

\title{
First fission-track age for the dinosaur-bearing Neuquén Group (Upper Cretaceous), Neuquén Basin, Argentina
}

\author{
Hugo CORBELLA ${ }^{1,2}$, Fernando E. NOVAS ${ }^{1,3}$, Sebastián APESTEGUIA ${ }^{1,4}$ \& Héctor A. LEANZA ${ }^{5,6}$ \\ ${ }^{1}$ Museo Argentino de Ciencias Naturales "Bernardino Rivadavia" and CONICET, Av. A. Gallardo 470, \\ 1405 Buenos Aires, Argentina, ${ }^{2}$ hcorbel@fibertel.com.ar. ${ }^{3}$ fernovas@yahoo.com.ar. \\ "paleoninja@yahoo.com.ar. ${ }^{5}$ Servicio Geológico Minero Argentino and CONICET. \\ Av. Julio A. Roca 651 Piso 10, 1322 Buenos Aires, Argentina. ${ }^{6}$ hleanz@osecind.mecon.gov.ar
}

\begin{abstract}
The first radiometric age for the Neuquén Group, based on fission-track analysis made on an ashflow tuff at the base of the Huincul Formation, is reported in this paper. The radiometric age offers a more precise chronological dating for the time of deposition of the first stages of the Neuquén Group. The tuff, exposed at Cerro Policía hill and other close localities in the Río Negro Province (NW Patagonia), has yielded a radiometric age of $88 \pm 3.9$ My. This value suggest that the Huincul Formation was deposited between an age range from 84.1 to $91.9 \mathrm{My}$, that is from the base of the Turonian to the top of the Santonian.
\end{abstract}

Key words: Upper Cretaceous, Neuquén Basin, Patagonia, geochronology, tetrapods.

Because of its areal extension, thickness and fossil tetrapod abundance (see Leanza et al., 2004), the Neuquén Group is one of the most important Cretaceous continental units in South America. Its beds, widely exposed in northwestern Patagonia, have been explored since the end of 19 th century particularly in the search for vertebrate remains. The Neuquén Group contains a wide variety of different groups of tetrapods, mainly reptiles, which currently represent the most complete and chronologically comprehensive sequence of Cretaceous continental fossil assemblages in the Southern continents. Due to its abundance in dinosaur remains, Keidel (1917) originally termed these beds as "Estratos con Dinosaurios." However, the age of the entire Neuquén Group, as well as each of its constituent subunits, is far from settled and mostly relies on the limiting ages of the under-and overlying marine formations, as well as on sequence stratigraphy analysis (Legarreta \& Uliana, 1998; Leanza, 1999; Leanza \& Hugo, 2001, Hugo \& Leanza, 2001).

Although magnetostratigraphic data were obtained for the upper part of the Neuquén Group (Dingus et al., 2000), rocks suitable for dating by radiometric methods in the Cretaceous continental strata of the Neuquén basin were almost unknown. The exception is the tuff level reported by Ramos (1981) from the Anacleto
Formation at Cerro los Overos (Neuquén Province), but this rock level still awaits to be radimetrically dated. Here we offer for the first time a fission-track age for the Neuquén Group.

\section{GEOLOGICAL AND PALEONTOLOGICAL SETTINGS}

The Neuquén basin is located in west central Argentina and eastern Chile between $34^{\circ}$ and $41^{\circ}$ S. In Argentina, their outcrops are exposed in the provinces of Neuquen (from which it takes the name), Mendoza, Río Negro, and La Pampa (Digregorio \& Uliana, 1980; Legarreta \& Uliana 1991; Gulisano \& Gutiérrez Pleimling, 1995). The Neuquén Group (Stipanicic et al., 1968) in this region lies between the Bajada del Agrio and Malargüe Groups, and is bounded by two major regional surfaces recognized as seismic reflector horizons: the Main Miranican (Albian/Cenomanian boundary) and the Huantraiquican (MidCampanian) unconformities (see Ramos, 1981, Macellari, 1988, Vergani et al., 1995, Leanza, 1999). It consists of continental red beds up to $1,300 \mathrm{~m}$ in thickness (Cazau \& Uliana, 1973), including conglomerates, sandstones, and mudrocks, dominantly deposited under alluvial processes (Legarreta \& Uliana, 1998). It is generally accepted that the Neuquen Group is Cenomanian to Early Campanian in age 


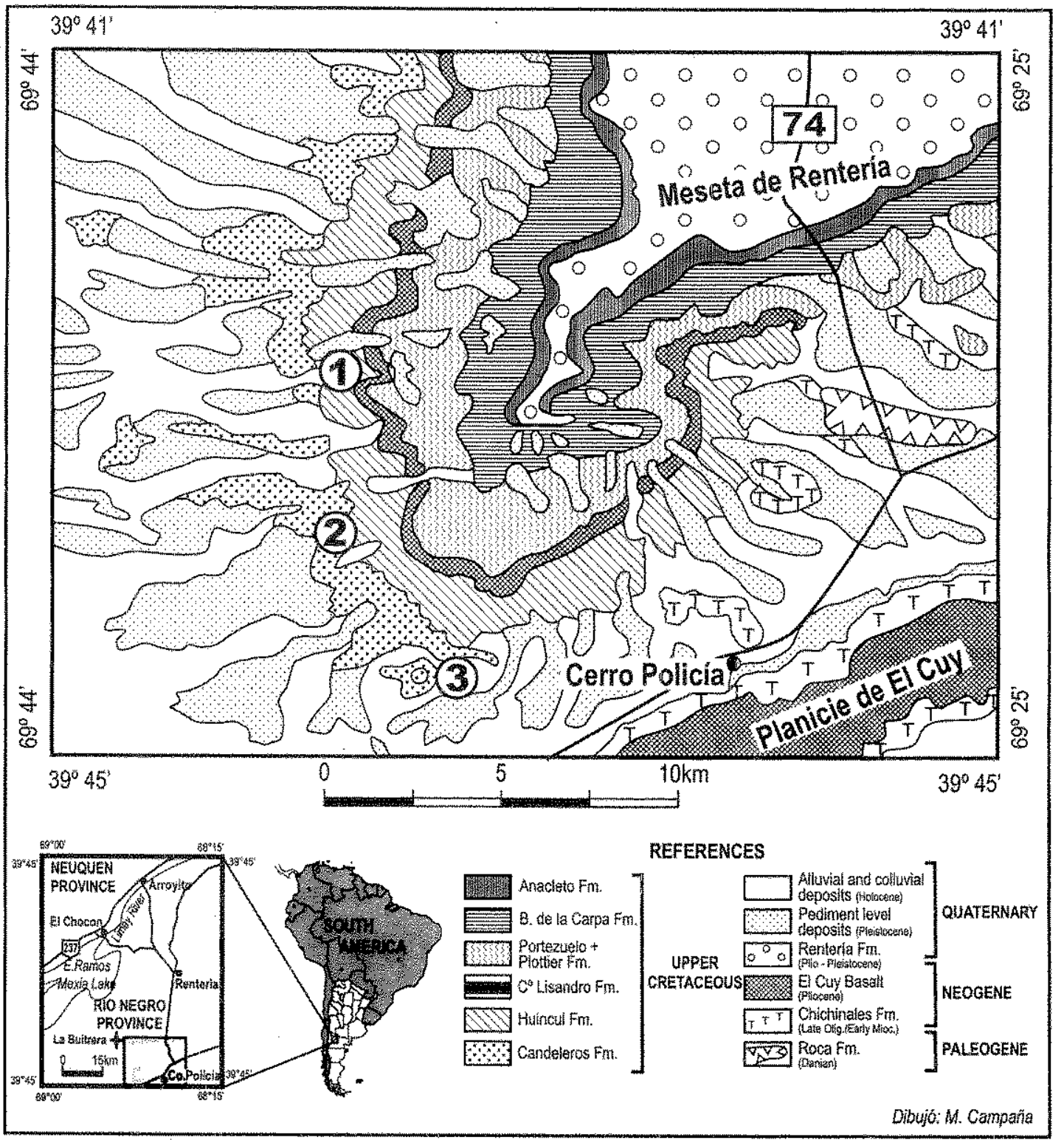

Fig. 1. Geological map showing location of the studied area (down left) and the three places in which the ash-flow tuff was studied: 1) Agua de las Vacas, 2) La Piedra Sola, and 3) Cerro Policía hill.

(Legarreta \& Uliana, 1998, Leanza \& Hugo, 2001, Hugo \& Leanza, 2001).

Current subdivision of the Neuquén Group embraces, from base to top, three fining upward cycles of continental deposition (Cazau \& Uliana, 1973): Río Limay, Río Neuquén and Río Colorado Subgroups. The Río Limay Subgroup is made up by three formational units: Candeleros, Huincul, and Cerro Lisandro.

Dinosaur remains discovered in this unit were found in different fossil spots located in a wide area around the Limay River, in the border between Neuquén and Río Negro Provinces. So far, two dinosaur taxa from the Huincul Formation have been named: the titanosaurian sauropod Argentinosaurus huinculensis (Bonaparte \& Coria, 1993) and the abelisauroid theropod Ilokelesia aguadagrandensis (Coria \& Salgado, 2000 ), but there are also abundant remains of carcharodontosaturid and abelisauroid theropods (Coria \& Currie, 1997; Novas \& Bandyopadhyay, 1999; de Valais et al., 2002), rebbachisaurid and 

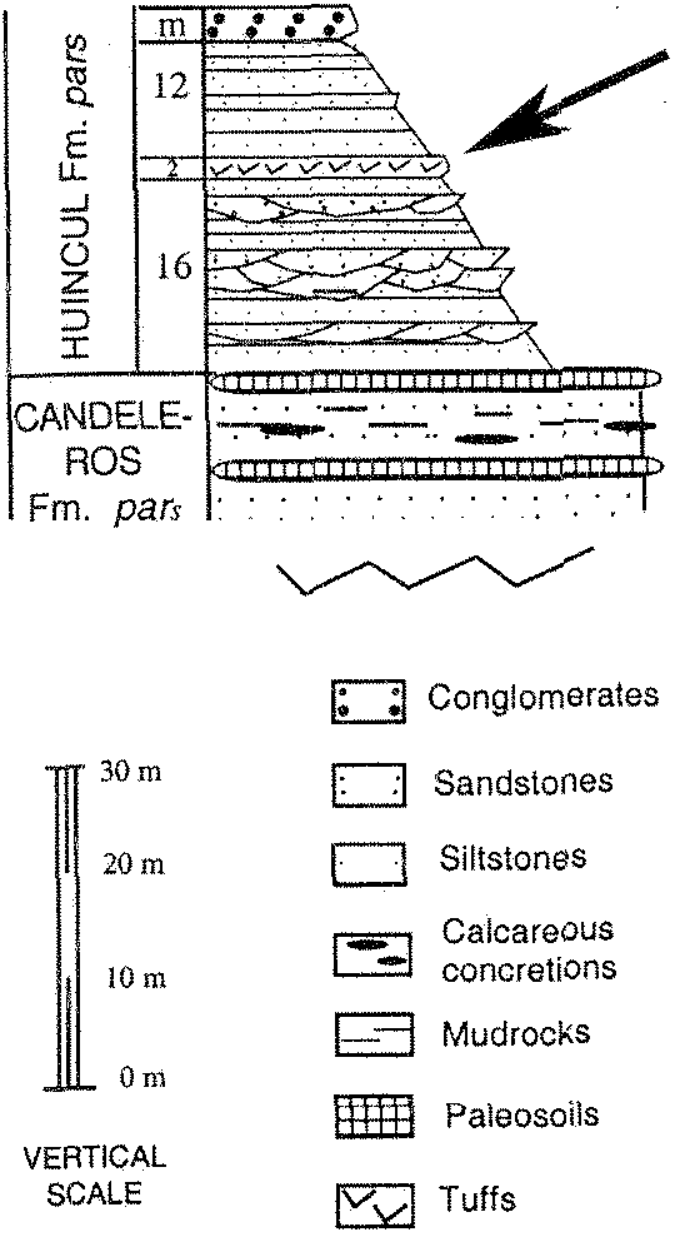

Fig. 2. Stratigraphic column at Cerro Policía hill, showing the position (arrow) of the radiometrically analyzed tuff in the basal portion of the Huincul Formation.

titanosaurian sauropods (Calvo \& Salgado, 1995; Calvo, 1999; Salgado et al., 1991; Simón, 2001). Basal euiguanodontian ornithopods originally reported from the Huincul Formation (Coria, 1999) are now referred to the overlying Cerro Lisandro Formation (R. Coria, pers, comm.).

\section{Characteristics and radiometric age of the tuff bed}

Pioneering work of Wichmann (1934) led to the identification of a white tuff bed at the Cerro Policía (Río Negro Province), close to the southern coast of the Lago Ezequiel Ramos
Mexía. Hugo \& Leanza (2001) later demonstrated that this white level is stratigraphically situated in the lower part of the Huincul Formation. For the purposes of this paper, the tuff level has been examined in three localities extending at least $10 \mathrm{~km}$ around the southwestern extremity of Meseta de Rentería region (Fig. 1), as follows: 1) Agua de las Vacas (S $39^{\circ} 35^{\prime}-$ W $68^{\circ} 37^{\prime}$; Fig. 3B), 2) La Piedra Sola (S $39^{\circ} 36^{\circ}-\mathrm{W} 68^{\circ} 43^{\prime}$; Fig. 3C), and 3 ) the Cerro Policía hill (S $39^{\circ} 40^{\prime}-\mathrm{W} 68^{\circ}$ 29', Fig. 3A).

The tuff level, which is interpreted as an ashflow (Ross \& Smith, 1960; Llambias, 2003) was collected $16 \mathrm{~m}$ above the base of the Huincul Formation (see Fig. 2), and it may reach up to $2.80 \mathrm{~m}$ in thickness. It is composed by reworked materials, including abundant glass shards strongly altered in zeolites (heulandite. clinoptilolite series), crystalloclasts of alkali feldspars, scarce ferromagnesian minerals, tiny crystals of Fe-Ti oxides, rutile and zircon. The internal structure of the tuff is locally massive, but more commonly shows marked contorted lamination suggesting at least local remobilization. The basal decimeters have abundant endichnial burrows up to $2 \mathrm{~cm}$ in diameter (Fig. 3D). Interbedded colored clastic lenses similar to the over or underlying sediments are common. The top of the white level is commonly eroded and covered by microconglomerates.

Selected zircon crystals of the white tuff level, outcropping at Agua de Las Vacas site, were dated by fission-track method at Geotrack Institute of Melbourne, Australia (see Table 1). Fission-track ages were determined from twenty grains chosen from a field zircon crystal concentrate. The final zircon concentrate comprises a suite of colorless, elongate euhedral grains. The sample shows a significant spread of ages, with the following four age groupings (error quoted at the \pm 10 level): $271.0 \pm 32.0 \mathrm{My}(3$ grains); $157.4 \pm 17.7 \mathrm{My}(2$ grains); $88.0 \pm 3.9 \mathrm{My}$ (14 grains); $50.5 \pm 8.8 \mathrm{My}$ (1 grain). The youngest group is represented by only a single grain and this is regarded as anomalous. The $88.0 \pm 3.9 \mathrm{My}$ population dominates the sample (fourteen out of twenty grains) and is regarded as the best age estimated for the primary volcanism, which, according to the stratigraphic chart of the International Commission on Stratigraphy (Gradstein \& Ogg, 2004), belongs to an age near the Turonian Coniacian boundary. The older ages represent a detrital input from surrounding basement rocks, presumably the Jurassic rhyolites from the Marifil Formation and the Permo-Triassic granitoids from the Curacó Complex (see Hugo \& Leanza, 2001). 

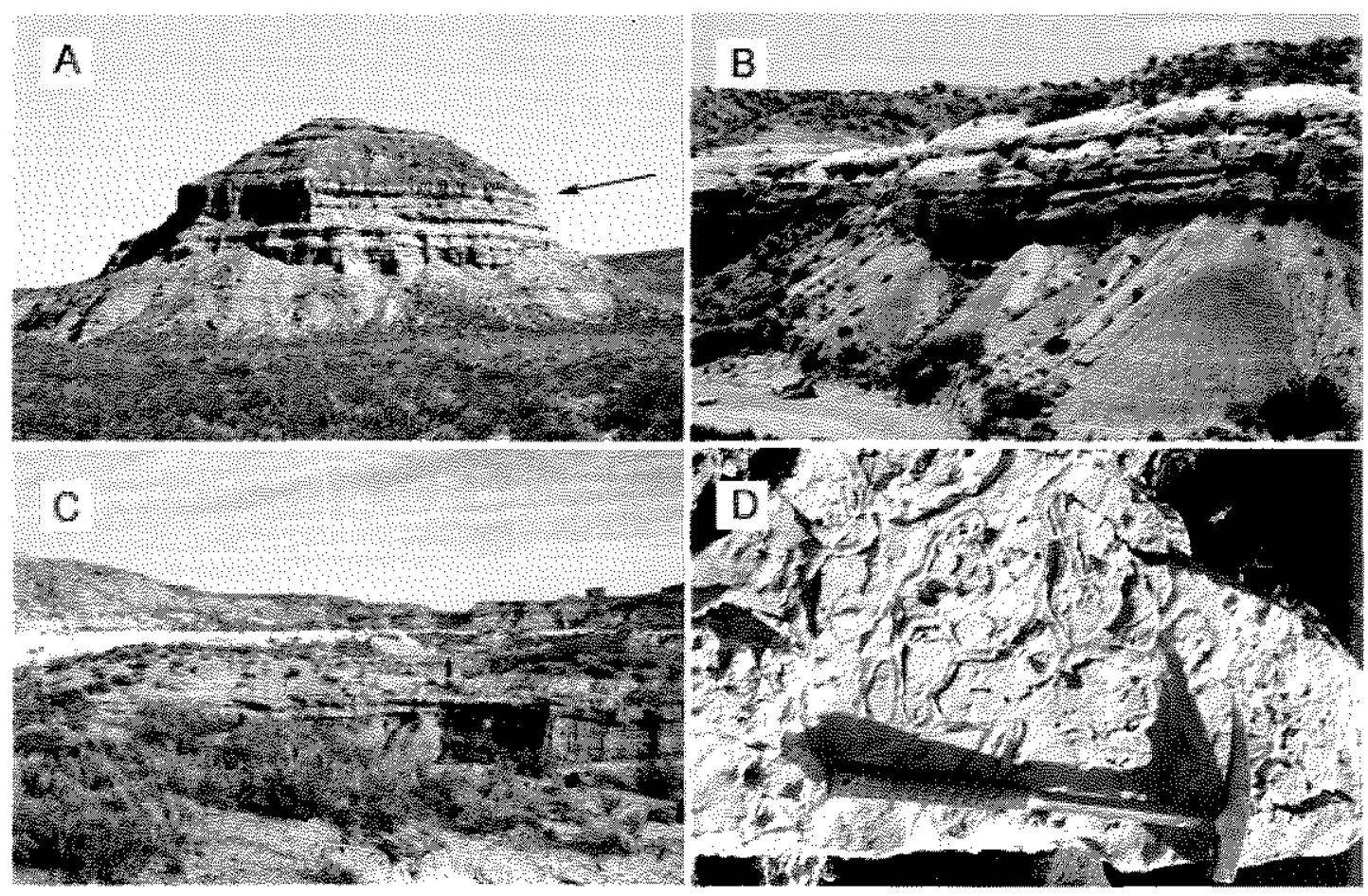

Fig. 3. Different aspects of the ash-flow tuff level in the Huincul Formation. A, Cerro Policia hill showing the white tuff level (arrow). B, the white tuff level (1.20 m thick) as expossed at the Agua de las Vacas site. $\mathbf{C}$, the white tuff level (2,80 m thick) at the La Piedra Sola locality. D, abundant endichnial burrows, up to $2 \mathrm{~cm}$ in diameter, present in the basal decimeters of the white tuff at the Cerro Policia site.

Table 1. Analytical values for the group of selected 14 zircon crystals. Pooled age $=88 \pm 3.9 \mathrm{My}$.

Number of spontaneous tracks in Ns grid squares

Number of induced tracks in Na grid squares

Spontaneous track density $=\mathrm{Ns} /(\mathrm{Na}$ *area of basic unit $)$

Induced track density $=\mathrm{N} 1 /(\mathrm{Na} *$ area of basic unit)

Ratio (Ns/Ni) = Uranium content of each grain

$\left(=\mathrm{U}\right.$ content of standard glass $* r_{i} / r$ )

Fission-track age, calculated using the equation B1.

Area of ione microscope eyepiece grid square

$\mathrm{c}^{2}$ parameter, used to assess variation of single grain ages within the sample

Probability of obtaining observed $\mathrm{c}^{2}$ value for the relevant number of degree of freedom, if all grains belong to a single population

\% variation in single grain ages

Pooled ratio, total spontaneous tracks divided bu total induced tracks for all grains

Mean of $(\mathrm{Ns} / \mathrm{Ni})$ for individual grains

Ages calculated using a zeta of $87.7 \pm 0.8$ for U3 glass

\author{
$\mathrm{N}_{\mathrm{s}}=2457$ \\ $\mathrm{Ni}=1197$ \\ $r_{\mathrm{S}}=7.596 \mathrm{E}+06$ \\ $r_{i}=3.701 \mathrm{E}+06$ \\ $\mathrm{U}(\mathrm{ppm})=$ \\ F. T. Age $(\mathrm{My})=$ \\ Area of basic unit $=6.293 \mathrm{E}-07 \mathrm{~cm}-2$ \\ $c^{2}=13.155$ with 13 freedom \\ $\mathrm{P}\left(\mathrm{c}^{2}\right)=43.6 \%$ \\ Age dispersion $=2.449 \%$ \\ $\mathrm{Ns} / \mathrm{Ni}=2.053 \pm 0.072$ \\ Mean radio $=2.105 \pm 0.085$ \\ $1_{\text {D } 9.840 \mathrm{E}=06 \mathrm{~cm} \cdot 2} \mathrm{ND}=1548$
}

\section{CONCLUSIONS}

The age of the Candeleros Formation was considered on the basis of its tetrapod content as Albian - Cenomanian or even Albian by some authors (i.e., Calvo, 1991, 1999), whereas others, on the basis of stratigraphic considerations, interpreted the age of this unit as Early Cenomanian (i.e., Vergani et al., 1995; Legarreta \& Uliana, 1998; Leanza, 1999). The overlying 
Huineul Formation was tentatively ascribed to the Late Cenomanian, and the Cerro Lisandro Formation to the Latest Cenomanian - Early Turonian (i.e., Leanza \& Hugo, 2001; Leanza et al., 2004). According to the present results, the Huincul and Cerro Lisandro Formations would be younger than previously thought, as radiometric data implies that the deposition of the first unit presumably started around the Early Turonian. Nevertheless, it might have persisted up to the Late Santonian if we consider the $3.9 \mathrm{My}$ error of the radiometric method.

However, this upward shift in age for the Huincul Formation does not necessarily imply a much younger age for the underlying Candeleros Formation, which is Late Cenomanian at least, as the similarities in faunal contents for both units may suggest that the time involved in their deposition was not significantly different. The age here presented supports the view that the Neuquén Group was quickly deposited in an interval between (Late?) Cenomanian and MidCampanian.

\section{ACKNOWLEDGEMENTS}

To Mike Thomson for improving an early version of this manuseript. Field trips to the studied area were supported by the Agencia Nacional de Promocion Cientifica y Técnica and The National Geographic Society (to FEN) and The Jurassic Foundation (to SA). To these institutions the authors are highly indebted. The authors are grateful to Mario Campaña (Universidad de La Plata) for digital drawings, and the Salinas and Avelás farmilies for their great help in the field, as well as to Mrs. Lidia Fernandez, from Cerro Policia town. To Ricardo Melchor and Rodolfo Coria for insightful comments on an earlier version of this manuscript.

\section{BIBLIOGRAPHY}

Bonaparte, J. F. \& R. A. Coria. 1993. Un nuevo y gigantesco saurópodo titanosaurio de la Formación Rio Limay (Albiano - Cenomaniano) de la provincia del Neuquén, Argentina. Ameghiniana 30 (3):271-282.

Calvo, J. 1991. Huellas de dinosaurios en la Formación Río Limay (Albiano-Cenomaniano), Picún Leufú, Prov, del Neuquén, República Argentina (Ornithischia, Saurischia, Sauropoda, Theropoda). Ameghiniana, 28(3-4):241-258.

1999. Dinosaurs and other vertebrates of the lake Ezequiel Ramos Mexía area, Neuquén - Patagonia, Argentina. National Science Musetum Monographs, 15:13-45.

Calvo, J.O., \& I. Salgado. 1995. Rebbachisaurus tessonei sp. nov., a new Sauropoda from the Abian-
Cenomanian of Argentina; new evidence on the origin of the Diplodocidae. Gaia 11:13-33.

Cazau, L. B. \& M. A. Uliana. 1973. El Cretácico Superior continental de la Cuenca Neuquina. $V$ Congreso Geológico Argentino, $3: 131-163$.

Coria, R. 1999. Materiales de ornitópodos de los niveles inferiores del Grupo Neuquén. Ameghiniana 36 (4) suppl.: $9 \mathrm{R}$.

Coria R. \& P. Currie. 1997. A new theropod from the Rio Limay Formation. Journal of Vertebrate Paleontology, 17(3):40A.

Coria, R. \& L. Salgado. 2000. A basal Abelisauria Novas 1992 (Theropoda - Ceratosauria) from the Cretaceous of Patagonia, Argentina. Gaia 15:89. 102.

De Valais, S., Novas, F. F., \& S. Apesteguía 2002. Morfología del pie de los terópodos abelisaurios: nuevas evidencias del Cretácico de Patagonia. Ameghiniana 39(4) suppl.:9R.

Digregorio, J. H. \& M. A. Uliana. 1980. Cuenca Neuquina. In: Geología Regional Argentina. Actdemia Nacional de Ciencias (Cordoba) 2:985-1032.

Dingus L., Clarke J., Scott G., Swisher III, C., Chiappe L., \& R. Coria. 2000. Stratigraphy and magnetostratigraphic/faunal constraints for the age of sauropod embryo-bearing rocks in the Neuquén Group (Late Cretaceous, Neuquén Province, Argentina). American Museum Novitates, 3290:1-11.

Gradstein, F. M. \& J. Ogg. 2004. A geological time scale 2004. International Commission on Stratigraphy. University of Cambridge Press.

Gulisano, C. \& A. Gutiérrez Pleimling. 1995. Field guide: The Jurassic of the Neuquen Basin. a) Neuquén province. Asociación Geológica Argenti. na, Serie E, 2:1-111.

Hugo, C. A. \& H. A. Leanza. 2001. Hoja Geológica 3969 IV General Roca, provincias del Neuquén y Río Negro. Instituto de Geologia y Recursos Naturales. SEGEMAR. Boletin 308:1-71.

Keidel, J. 1917. Über das patagonische Tafelland das patagonische Geröll und ihre Beriehungen zu den geologischen Erscheinungen im argentinischen Andengebiet und Litoral. Zeits. Deulch. Wissen. Vereins, $3(219-245): 311-333$.

Leanza, H, A. 1999. The Jurassic and Cretaceous terrestrial beds from Southern Neuquén Basin, Argentina. Field Guide. Instituto Superior de Correlación Geologica. INSUGEO. Serie Miscelánea 4:1-30. San Miguel de Tueumán.

Leanza, H. A \& C. A. Hugo. 2001. Cretaceous red-beds from southern Neuquén Basin (Argentina): age, distribution and stratigraphic discontinuties. $7^{\circ}$ International Symposium on Mesozoic Terrestrial Ecosystems, Asociación. Paleontólogica Argentina, Publicación Especial 7:111-122.

Leanza, H. A., Apesteguía, S., Novas, F. E. \& M. de la Fuente. 2004. Cretaceous terrestrial beds from the Neuquén Basin (Argentina) and their tetrapod assemblages. Creicceous Research, 25:61-87.

Legaryeta, L. \& M. A. Uliana. 1991. Jurassic/Cretaceous marine oscillations and geometry of a back-are basin fill, central Argentine Andes. In: Mc Donald D. I. M. (ed.): Sedimentation, Tectonics and Eustacy. International Association of Sedimentologists. 
Special Publication (London) 12:429-450.

- 1998. Anatomy of hinterland depositional sequences: Upper Cretaceous fluvial strata, Neuquén Basin, west central Argentina. In: Shanley, K. W. and McCabe, P. J. (eds.): Relative role of eustacy, climate, and tectonism in continental rocks. Society of Economic Paleontologists and Mineralogists, SEPM, Special Publication, 59:83. 92.

Llambías, E. J. 2003. Geología de los cuerpos ígneos. Asociación Geológica Argentina, Serie B, Didáctica y Complementaria - N2 $27: 1.182$.

Macellari, C. E. 1988. Cretaceous paleogeography and depositional cycles in western South America. Journal on South American Earth Science, 1:373418.

Novas, F. E. \& S. Bandyopadhyay. 2001 Abelisaurid pedal unguals from the Late Cretaceous of India. 72 International Symposium on Mesozoic Terrestrial Ecosystems, Asociación Paleontólogica Argentina, Publicación Especial 7:145-149.

Ramos, V. A. 1981. Descripción geológica de la Hoja 33c, Los Chihuidos Norte, provincia del Neuquén. Servicio Nacional Minero Geológico, Boletín 1.82.

Ross, C. S. \& R. L. Smith. 1960. Ash-flow tuffs: their origin, geologic relations and identification. Geological Survey Professional Paper 366 : 1.81.

Salgado, L., Calvo J. \& R. Coria. 1991. Estudio preliminar de dinosaurios saurópodos de la Formación Río Limay (Cretácico presenoniano, provincia del Neuquén). Ameghiniana, 28 (1-2):134.

Simón, M. 2001. A giant sauropod from the Upper Cretaceous of El Chocón, Neuquén, Argentina. Ameghiniana 38(4) suppl.:19R.

Stipanicic, P. N., F. Rodrigo, O. L. Baulíes \& C. G. Martínez. 1968. Las formaciones presenonianas del denominado Macizo Nordpatagónico y regiones adyacentes. Revista de la Asociación Geológica Argentina, 23(2):367-388.

Vergani, G. D., A. J. Tankard, H. J. Belotti, \& H. J. Welsink. 1995. Tectonic evolution and paleogeography of the Neuquén Basin, Argentina. In: A.J. Tankard, R. Suárez and H. J. Welsink (eds.); Petroleum basins of South America. American Association of Petroleum Geologists, Memoir 62:383-402.

Wichmann, R. 1934. Contribución al conocimiento geológico de los Territorios del Neuquén y del Río Negro. Direceión de Minas y Geología, Boletín 39:127. 